Brit. F. vener. Dis. (1968), 44, 319.

\title{
TREATMENT OF GONOCOCCAL URETHRITIS WITH SINGLE INJECTIONS OF 2.4 MEGA UNITS OF AQUEOUS PROCAINE PENICILLIN*
}

\author{
BY \\ G. D. MORRISON, R. J. C. COBBOLD, S. BOR, R. J. SPITZER, \\ D. N. FOSTER, AND R. R. WILLCOX \\ St. Mary's Hospital, London, W.2
}

Owing to the emergence of more resistant strains of gonococci the position of penicillin is seriously threatened; streptomycin, with a failure rate exceeding 30 per cent. in London (Spitzer and Willcox, 1968) has ceased to be a useful drug in this condition; and the writing is already on the wall for the tetracyclines and some other antibiotics.

Even after penicillin had been in widespread use for 6 to 7 years the minimal recommended dose for gonorrhoea was only 100,000 units (Hogan, Johnwick, Hanchett, Harb, and Adar, 1950), and at St. Mary's Hospital at that time over 90 per cent. of cases were cured with a single injection of 150,000 units procaine penicillin in oil with aluminium monostearate (PAM). Indeed, it was largely the observation that 300,000 units of PAM might cure four out of five cases of early syphilis (Wright, Nicholson, and Arnold, 1950) which led to the first increases in dosage for gonorrhoea so as to be more sure of aborting the more serious disease if it were also present.

In time, in spite of increased dosage (Streitmann and Krassnigg, 1957; Knight, 1958; Willcox, 1958), failure rates to penicillin began to mount, particularly in Europe, although by no means simultaneously in all areas (Schmidt, 1961). If laboratory evidence of increased numbers of less sensitive strains of gonococci was at first inconclusive (Hawks and Greey 1948; Del Love and Finland, 1955), this too in time was provided from the USA (Thayer, Field, Magnuson, and Garson, 1957) and from Denmark (Reyn, Korner and Weis Bentzon, 1958) and elsewhere. The clear demonstrations from London (Curtis and Wilkinson, 1958; Cradock-Watson, Shooter, and Nicol, 1958) of the direct association of the strains of gonococci less sensitive to penicillin with cases showing clinical failure to the antibiotic have since been amply confirmed by many other

* Received for publication December 13, 1967. workers (see for example Juhlin and Krook, 1965).

To-day strains of gonococci requiring 2 units of penicillin per $\mathrm{ml}$. or more for inhibition are being encountered in Europe (Aepinus, 1965; Hejzlar and Vymola, 1965) and incidences of less sensitive strains as high as 30 to 50 per cent. have been reported from Denmark (Reyn, 1963), Finland (Rantasalo, 1962), Greenland (Lomholt and Berg, 1966), Norway (Gjessing, 1963), and Yugoslavia (Grin and Karlovac, 1965), while figures of from 12 to 30 per cent. have been noted in other areas (see Willcox, 1967). However, lack of standardization of methods of sensitivity measurement and of definition of a "less sensitive" strain have made exact comparison difficult. Nevertheless strains less sensitive to penicillin are usually completely resistant to streptomycin and vice versa (Reyn, 1963; Thayer, Samuels, Martin, and Lucas, 1965; Grin and Karlovac, 1965).

With mounting failure rates in some areasparticularly in the Far East (Bodenbender, 1960; Smedley, 1960; Sabath and Kivlahan, 1961)-the first adjustment to the situation was to abandon the use of repository penicillins, especially benzathine penicillin, and to give larger doses of shorter-acting penicillins; a régime consisting of single doses of $1 \cdot 2$ mega units aqueous procaine penicillin is still widely used for male cases in this country.

By increasing the dosage not only have failure rates been at least temporarily reduced but the incidence of less sensitive strains has been noted to decline in the clinics concerned (Letchner and Nicol, 1961; Morton, 1963; Morton and Higson, 1966). Nevertheless, even with $1 \cdot 2$ mega units procaine penicillin, failure rates of 8 to 12 per cent. have been reported (Tiedemann, Hackney, Simpson, and Price, 1962; Willcox, 1964) and further dosage increases to $1 \cdot 8-2 \cdot 4$ mega units have been recommended by the International Union against the Venereal Diseases (Brit. F. vener. Dis., 1961) and by 
the WHO Expert Committee on Gonococcal Infections (WHO, 1963). It has been suggested, however, that even with 1.8 mega units a failure rate of 10 per cent. might still be expected (Klaschka, Hannemann, and Ränike, 1963).

Nevertheless, unlike the situation with streptomycin for which complete resistance is the rule, the situation with penicillin remains one of lessened sensitivity, and the statement of Finland (1955) that no authentic report of a completely penicillinresistant gonococcus exists is still acceptable.

Bearing in mind the undisputed advantages of a single dose method for the treatment of a communicable disease such as gonorrhoea, and the very large margin of safety still available with penicillin before falling foul of toxicity risks, larger doses of aqueous procaine penicillin have been used in the USA. Employing single doses of $2 \cdot 4-2 \cdot 5$ mega units aqueous procaine penicillin on military and gaol populations, the failure rates have been reduced to less than 2.5 per cent. (Sokoloff and Goldstein, 1963; Staheli, 1964; Ashamalla, Walters, and Crahan, 1966), figures once again similar to those obtained when penicillin was first introduced. Previous experience suggests that failure rates are unlikely to remain low and it is still important to watch the results of treatment with penicillin and to test new methods.

\section{Present Investigation}

No reports have been published concerning the use of single injections of $2 \cdot 4$ mega units aqueous procaine penicillin in the United Kingdom. An investigation was therefore made into the effects of such a schedule on 280 male patients with acute uncomplicated previously untreated gonorrhoea in London, and the results are contrasted with those obtained in 238 other patients treated with half this amount.

\section{Treatment with Single Injections of 2.4 mega} units Procaine Penicillin

\section{Material}

Country of Origin Of the 280 patients given $2 \cdot 4$ mega units, 121 were Negroes (101 from the West Indies, 12 from West Africa, 5 from South America, 2 from East Africa, and 1 from the USA), 99 were born in the United Kingdom, and sixty were "other immigrants" from 27 different countries (15 from Eire, 5 from Spain, 4 from Cyprus, 3 each from Greece, Pakistan, and the USA, 2 each from India, Hungary, Libya, Norway, Poland, and Portugal, and 1 each from Algeria, Bahrain, Canada, Ceylon, Denmark, France,
Germany, Hong Kong, Iraq, Italy, Malaysia, Mauritius, Mexico, Rhodesia, and Switzerland).

\section{Age The average age was $28 \cdot 7$ years.}

Marital Status 213 were single, 66 were married, and one was a widower.

History of Venereal Disease There was no previous history of venereal disease in 120 of these patients. The remainder had had no less than 423 attacks of gonorrhoea, 99 of non-gonococcal urethritis, thirteen of syphilis, four of non-specific proctitis, and one of condylomata acuminata; one patient had been treated epidemiologically as a syphilis contact.

Of the 99 persons born in the United Kingdom, 53 (53.6 per cent.) were attending for the first infection while the remainder had had 98 previous episodes (including all four attacks of proctitis) with an average of 1.0 for the whole group. The figures for the sixty "other immigrants" were not dissimilar, as thirty (50 per cent.) were attending for the first time and the remainder had suffered 46 previous episodes (average 0.8 for the group). Of the 121 Negro patients, on the other hand, only 37 (30.6 per cent.) were making their first appearance and the remainder had had no less than 397 previous episodes (including $\mathbf{3 2 0}$ of gonorrhoea and 66 of non-gonococcal urethritis), giving an average for this group of $3 \cdot 3$. These figures were boosted by five West Indian "repeaters" with $35,31,21,19$, and 18 previous episodes, respectively, the nearest comparable patient in the other groups being one man born in the United Kingdom with fourteen previous episodes.

Symptoms before Treatment The discharge had been present before treatment for 1 to 3 days in 224 patients; for 4 to 7 days in 39 , for 8 to 14 days in ten, for 15 to 21 days in four, for over 28 days in two, and for an unknown period in one; 194 patients complained of some dysuria, $83 \mathrm{did}$ not, and there was no record in three.

Source of Infection The disease had apparently been contracted from a female stranger in 121 cases (stated as being a prostitute in nine), from a female friend in 120, and from the wife in six. In thirty instances it was acquired from a male source (a male stranger in eleven, a friend in eighteen, and unspecified in one). The nature of the source was not noted in three cases.

Incubation Period The apparent incubation period was 1 to 3 days in 119 cases, 4 to 7 days in 98,8 to 14 days in 44,15 to 21 days in six, 22 to 28 days in three, over 28 days in seven, and unknown in three.

Sero-Reactivity The routine Wassermann and VDRL reactions were both negative in 257 cases, the Wassermann reaction was negative and the VDRL positive in four, and both tests were positive in seventeen. There was no record in two cases. Of the 21 seroreactors fourteen were Negroes; the reactivity was doubtless due to previous yaws in some patients, four of whom gave a positive history of the disease. 


\section{Case Management}

In both series the diagnosis of gonorrhoea was based on findings in a Gram-stained urethral smear taken in all cases before treatment, when blood for a routine serum test for syphilis was also taken. At first, when $2 \cdot 4$ mega units of aqueous procaine penicillin were used, two injections were given, $4 \mathrm{ml}$. into each buttock, but when it was established that the $8 \mathrm{ml}$. dose could be well tolerated in a single depot, it was then given in this way. Apart from one patient who complained of local pain, the tolerance appeared to be much the same as with a $4 \mathrm{ml}$. dose.

After treatment the patients were instructed to attend again after 2 to 3 days when the urethra was examined for discharge (a smear being taken if any were present) and the urine was examined for haze and threads. Subsequently, it was intended that the patients should be seen approximately $1,4,8$, and 12 weeks after treatment, with a final serum test for syphilis at 3 months, one examination of the prostatic fluid being made during this period.

\section{Follow-up and Results (Table I)}

By no means all the patients attended as requested, but sufficient time elapsed before assessment for all patients to have been followed for 3 months; of the 280 patients treated, 240 were followed. The status at the last visit was satisfactory in 135 patients, 54 were treated for non-gonococcal infection, and 37 who gave a history of further sexual exposure were re-treated for re-infection with gonorrhoea. There were fourteen apparent failures to treatment including relapses ( $5 \cdot 8$ per cent.).

TABLE I

FOLLOW-UP AND RESULTS IN 280 PATIENTS

\begin{tabular}{|c|c|c|c|c|c|}
\hline \multirow[b]{2}{*}{$\begin{array}{l}\text { Length of } \\
\text { Follow-up }\end{array}$} & \multirow[b]{2}{*}{$\begin{array}{l}\text { No. } \\
\text { Followed }\end{array}$} & \multicolumn{4}{|c|}{ Result } \\
\hline & & $\begin{array}{c}\text { Satis- } \\
\text { factory }\end{array}$ & $\begin{array}{c}\text { Non- } \\
\text { gonococcal } \\
\text { Infection }\end{array}$ & $\begin{array}{c}\mathrm{Re}- \\
\text { infection }\end{array}$ & $\begin{array}{c}\text { Suspected } \\
\text { Failure }\end{array}$ \\
\hline $\begin{array}{l}\text { 1-3 days } \\
4-7 \text { days } \\
8-14 \text { days } \\
15-21 \text { days } \\
22-28 \text { days } \\
1-2 \text { mths } \\
2-3 \text { mths } \\
\text { More than } \\
3 \text { mths }\end{array}$ & $\begin{array}{r}240 \\
186 \\
146 \\
97 \\
81 \\
65 \\
28 \\
3\end{array}$ & $\begin{array}{r}40 \\
27 \\
26 \\
9 \\
10 \\
15 \\
7 \\
1\end{array}$ & $\begin{array}{r}11 \\
8 \\
13 \\
5 \\
2 \\
8 \\
7 \\
-\end{array}$ & $\begin{array}{r}-1 \\
5 \\
1 \\
3 \\
14 \\
11 \\
2\end{array}$ & $\begin{array}{r}3 \\
4 \\
5 \\
1 \\
1 \\
- \\
-\end{array}$ \\
\hline Total & 240 & 135 & 54 & 37 & $\begin{array}{c}14 \\
(5 \cdot 8 \\
\text { per cent.) }\end{array}$ \\
\hline
\end{tabular}

No satisfactory criteria exist to distinguish relapse from re-infection apart from a history of further sexual exposure. Studies of penicillin sensitivity tests in recurrences following penicillin therapy have shown that, in recurrences occurring in the first week after treatment, a high proportion of less sensitive organisms is found, whereas in recurrences noted after this time the distribution of the less sensitive strains is similar to that found before the first treatment (Curtis and Wilkinson, 1958). It has been suggested, therefore, to avoid having to rely on the history of the patient, that it is reasonable to classify all recurrences in the first week as failures and all those appearing thereafter as re-infections, regardless of the history given. As the usually accepted incubation period of gonorrhoea is 1 to 14 days, the same technique has been used by some but taking the end of the second week from treatment as the dividing point.

In the figures presented it will be noted that there were eight recurrences in the first week (3.3 per cent.) and eighteen in the first two weeks ( $7 \cdot 5$ per cent.), while the failure rate based on the history alone was $5 \cdot 8$ per cent.

\section{Treatment with Single Injections of $1 \cdot 2$ mega units Procaine Penicillin}

The results obtained in a series of 238 cases using single injections of 1.2 mega units of procaine penicillin shortly before the larger dose of 2.4 mega units began to be used are shown in Table II.

TABLE II

FOLLOW-UP AND RESULTS IN 238 PATIENTS TREATED WITH SINGLE INJECTIONS OF $1 \cdot 2$ MEGA UNITS

\begin{tabular}{|c|c|c|c|c|c|}
\hline \multirow[b]{2}{*}{$\begin{array}{l}\text { Length of } \\
\text { Follow-up }\end{array}$} & \multirow[b]{2}{*}{$\begin{array}{l}\text { No. } \\
\text { Followed }\end{array}$} & \multicolumn{4}{|c|}{ Result } \\
\hline & & $\begin{array}{l}\text { Satis- } \\
\text { factory }\end{array}$ & $\begin{array}{c}\text { Non- } \\
\text { gonococcal } \\
\text { Infection }\end{array}$ & $\begin{array}{c}\text { Re- } \\
\text { infection }\end{array}$ & $\begin{array}{l}\text { Suspected } \\
\text { Failure }\end{array}$ \\
\hline $\begin{array}{l}\text { 1-3 days } \\
4-7 \text { days } \\
8-14 \text { days } \\
15-21 \text { days } \\
22-28 \text { days } \\
1-2 \text { mths } \\
2-3 \text { mths } \\
\text { More than } \\
3 \text { mths }\end{array}$ & $\begin{array}{r}200 \\
158 \\
116 \\
75 \\
57 \\
42 \\
22 \\
15\end{array}$ & $\begin{array}{r}33 \\
31 \\
22 \\
11 \\
8 \\
11 \\
3 \\
2\end{array}$ & $\begin{array}{r}5 \\
5 \\
10 \\
5 \\
3 \\
4 \\
- \\
\end{array}$ & $\begin{array}{l}-1 \\
6 \\
1 \\
1 \\
4 \\
4 \\
9\end{array}$ & $\begin{array}{l}4 \\
5 \\
3 \\
1 \\
3 \\
1 \\
- \\
-\end{array}$ \\
\hline Total & 200 & 121 & 36 & 26 & $\begin{array}{c}17 \\
(8 \cdot 5 \\
\text { per cent. })\end{array}$ \\
\hline
\end{tabular}

Of 238 patients treated, 200 were followed. The status at the last visit was satisfactory in $121 ; 36$ were treated for a subsequent non-gonococcal infection and, as judged by a history of further sexual intercourse, 26 were re-treated for re-infection with gonorrhoea. There were seventeen suspected failures (8.5 per cent.). Expressed as the number of recurrences in the first and second weeks, irrespective of history of further exposure, the failure rates were 5 and $9 \cdot 5$ per cent. respectively.

\section{Comparison of the Two Series (Table III, opposite)}

Overall Results By all three methods of assessment the failure rates were apparently lower when a single dose of 2.4 million units was used. 
TABLE III

COMPARISON OF RESULTS IN THE TWO SERIES

\begin{tabular}{|c|c|c|c|c|c|c|c|c|c|}
\hline \multirow{2}{*}{ Race } & \multirow{2}{*}{ Schedule } & \multirow{2}{*}{ No. } & \multirow{2}{*}{ Followed } & \multicolumn{2}{|c|}{$\begin{array}{l}\text { All Recurrences } \\
\text { within } 7 \text { days }\end{array}$} & \multicolumn{2}{|c|}{$\begin{array}{l}\text { All Recurrences } \\
\text { within } 14 \text { days }\end{array}$} & \multicolumn{2}{|c|}{$\begin{array}{l}\text { Failures based } \\
\text { on History }\end{array}$} \\
\hline & & & & No. & Per cent. & No. & Per cent. & No. & Per cent. \\
\hline All Patients & $\begin{array}{l}1 \cdot 2 \text { mega units } \\
2.4 \text { mega units }\end{array}$ & $\begin{array}{l}238 \\
280\end{array}$ & $\begin{array}{l}200 \\
240\end{array}$ & $\begin{array}{r}10 \\
8\end{array}$ & $\begin{array}{l}5 \cdot 0 \\
3 \cdot 3\end{array}$ & $\begin{array}{l}19 \\
18\end{array}$ & $\begin{array}{l}9 \cdot 5 \\
7 \cdot 5\end{array}$ & $\begin{array}{l}17 \\
14\end{array}$ & $\begin{array}{l}8 \cdot 5 \\
5 \cdot 8\end{array}$ \\
\hline Negro & $\begin{array}{l}1.2 \text { mega units } \\
2.4 \text { mega units }\end{array}$ & $\begin{array}{r}80 \\
121\end{array}$ & $\begin{array}{r}69 \\
101\end{array}$ & $\begin{array}{l}4 \\
5\end{array}$ & $\begin{array}{l}5 \cdot 8 \\
5 \cdot 0\end{array}$ & $\begin{array}{r}9 \\
11\end{array}$ & $\begin{array}{l}13 \cdot 0 \\
10 \cdot 9\end{array}$ & $\begin{array}{l}9 \\
7\end{array}$ & $\begin{array}{r}13 \cdot 0 \\
6 \cdot 9\end{array}$ \\
\hline Other Races & $\begin{array}{l}1.2 \text { mega units } \\
2.4 \text { mega units }\end{array}$ & $\begin{array}{l}158 \\
159\end{array}$ & $\begin{array}{l}131 \\
139\end{array}$ & $\begin{array}{l}6 \\
3\end{array}$ & $\begin{array}{l}4 \cdot 6 \\
2 \cdot 2\end{array}$ & $\begin{array}{r}10 \\
7\end{array}$ & $\begin{array}{l}7 \cdot 6 \\
5 \cdot 0\end{array}$ & $\begin{array}{l}8 \\
7\end{array}$ & $\begin{array}{l}6 \cdot 1 \\
5 \cdot 0\end{array}$ \\
\hline
\end{tabular}

\section{Discussion}

The failure rates in the Negro patients given $1 \cdot 2$ mega units varied between 5.8 and 13 per cent. according to the method of assessment, and these were reduced to between 5.0 and 10.9 per cent. when the dosage was increased to $2 \cdot 4$ mega units.

In patients of other races the failure rates in those given 1.2 mega units ranged from $4 \cdot 6$ to $6 \cdot 1$ per cent. and these were reduced to from $2 \cdot 2$ to $5 \cdot 0$ per cent. when the double dosage was employed.

In view of the much higher incidence of previous infections with gonorrhoea among the Negro patients, their higher apparent failure rates in both series are considered to be due to a higher incidence of re-infection.

The apparent superiority of treatment with $2 \cdot 4$ mega units of penicillin is best revealed when assessment of treatment failure is based on the patient's history; there were fourteen failures in the group of 240 cases followed after treatment with $2 \cdot 4$ mega units but seventeen failures among the 200 cases followed after treatment with $1 \cdot 2$ mega units. However, application of the $\chi^{2}$ test shows that this difference is not statistically significant, a finding which is contrary to previous experience of the effects of dosage increase. Indeed, for the figures to be so, it would have been necessary to have treated some 725 cases (perhaps more) in each series (Rose, 1968). It would seem probable, apart from the fluctuations in penicillin sensitivity which are known to occur with time, that the current incidence of gonococci markedly less sensitive to penicillin in London was not high enough for a decisive result to have been obtained in the series reported.

\section{Summary and Conclusions}

(1) The decline in the effectiveness of penicillin in the treatment of gonorrhoea over the years with the necessity of repeatedly increasing the dosage is described.
(2) The results are presented of the treatment of 280 cases of acute uncomplicated gonorrhoea in London with single injections of $2 \cdot 4$ mega units aqueous procaine penicillin in 1967; these results are contrasted with those in an earlier series of 238 other cases given single injections of $1 \cdot 2$ mega units.

(3) Of 280 patients given 2.4 mega units, 240 were followed and, based on a history of no additional sexual exposure, there were fourteen failures $(5 \cdot 8$ per cent.). If all eight recurrences in the first week, regardless of history, were classified as failures, the failure rate was 3.3 per cent., and if all eighteen recurrences in the first 2 weeks were so counted it was $7 \cdot 5$ per cent.

(4) These results were apparently better than when 1.2 mega units was used, when the percentages were $8 \cdot 5,5 \cdot 0$, and 9.5 respectively. However, statistical analysis of these results shows that the differences are not significant, a fact which is probably due to relatively low incidence of markedly less sensitive organisms in circulation at the time which therefore required two much larger series to show a significant difference.

(5) It is probable that the overall pattern of declining sensitivity of circulating gonococcal strains will continue. It is feasible to make substantial further increases in the dosage of procaine penicillin in the future without falling foul of toxicity risks, but the limiting factor is clearly becoming the amount of host tissue into which to inject. It is necessary therefore that investigations of alternative treatments should continue as a safeguard for the future.

\section{REFERENCES}

Aepinus, M. (1965). Z. Haut u. Geschl.-kr., 39, 11. Ashamalla, G., Walters, N. R., and Crahan, M. (1966). F. Amer. med. Ass., 195, 1115.

Bodenbender, R. H. (1960). U.S. armed Forces med.F., 11, 1311.

Brit. F. vener. Dis. (1961). Editorial, 37, 89.

Cradock-Watson, J. E., Shooter, R. A., and Nicol, C. S. (1958). Brit. med. F., 1, 1091. 
Curtis, F. R., and Wilkinson, A. E. (1958). Brit.F. vener. Dis., 34, 70.

Del Love, B., Jr, and Finland, M. (1955). Arch. intern. Med., 95, 66.

Finland, M. (1955). New Engl. F. Med., 253, 909.

Gjessing, H. C. (1963). Nord. Med., 70, 866.

Grin, E., and Karlovac, K. (1965). Med. Arh. (Sarajevo), 19, March-April, p. 5.

Hawks, G. H., and Greey, P. H. (1948). Canad. F. publ. Hlth, 39, 74 (Abstr.).

Hejzlar, M., and Vymola, F. (1965). Ceš. Derm., 40, 23.

Hogan, R. B., Johnwick, W. B., Hanchett, L. J., Harb, F. W., and Adar, O. L. (1950). Э. vener. Dis. Inform., 31, 96.

Juhlin, I., and Krook, G. (1965). Läkartidningen, 62, 1250.

Klaschka, F., Hannemann, G., and Ränike, A. (1963). Dermatologica (Basel), 127, 269.

Knight, G. (1958). Brit. F. vener. Dis., 34, 223.

Letchner, E. H., and Nicol, C. S. (1961). Ibid., 37, 158.

Lomholt, G., and Berg, O. (1966). Ibid., 42, 1.

Morton, R. S. (1963). Ibid., 39, 105.

— and Higson, D. W. (1966). Ibid., 42, 175.

Rantasalo, I. (1962). Duodenum (Helsinki), 78, 372.

Reyn, A. (1963). Acta derm.-venereol. (Stockh.), 43, 380.

-, Korner, B., and Weis Bentzon, M. (1958). Brit. F. vener. Dis., 34, 227.

Rose, G. M. (1968). Personal communication.

Sabath, L. D., and Kivlahan, J. J. (1961). Amer. F. med. Sci., 242, 663.

Schmidt, H. (1961). Ugeskr. Laeg., 123, 749.

Smedley, M. G. (1960). F. roy. nav. med. Serv., 46, 119.

Sokoloff, B., and Goldstein, H. (1963). F. Amer. med. Ass., 184, 197.

Spitzer, R. J., and Willcox, R. R. (1968). Acta derm.venereol. (Stockh.) (in press).

Staheli, L. T. (1964). F. Amer. med. Ass., 190, 854.

Streitmann, B., and Krassnigg, A. (1957). Wien. klin. Wschr., 69, 317.

Tiedemann, J. H., Hackney, J. F., Simpson, W. G., and Price, E. V. (1962). Publ. Hlth Rep. (Wash.), 77, 485.

Thayer, J. D., Field, F. W., Magnuson, H. J., and Garson, W. (1957). Antibiot. and Chemother., 7, 306.

-, Samuels, S. B., Martin, J. E., and Lucas, S. B. (1965). "Antimicrobial Agents and Chemotherapy1964 ", p. 433.

WHO (1963). WHO Expert Committee on Gonococcal Infections, WHO Tech. Rep. Ser. No. 262. Geneva.

Willcox, R. R. (1958). Bull. Wld Hlth Org., 19, 503.

- (1964). Brit. F. vener. Dis., 40, 118.

- (1967). Paper presented at Fifth International Congress of Chemotherapy, Vienna, July, 1967.

Wright, R. D., Nicholson, F. P., and Arnold, R. C. (1950). F. vener. Dis. Inform., 31, 235.
Le traitement de l'urétrite blennorragique

par une injection unique de $\mathbf{2 , 4}$ méga unités de procaine pénicilline aqueuse

\section{Résumé et Conclusions}

(1) La diminution de l'éfficacité de la pénicilline dans le traitement de la blennorragie depuis des années ainsi que la nécessité d'augmentations répétées du dosage sont décrites.

(2) Les résultats sont présentés au sujet du traitement de 380 cas de blennorragie aiguë sans complications à Londres par une injection unique de 2,4 méga unités de procaïne pénicilline aqueuse pendant 1967; ces résultats sont comparés à ceux d'une série ultérieure de 235 autres cas qui avaient reçu des injections uniques de 1,2 méga unités.

(3) Des 280 malades qui avaient reçu 2,4 méga unités, 240 avaient été suivis, et, se basant sur l'historique d'aucune promiscuité sexuelle additionnelle, il y avait eu 14 cas d'insuccès au traitement $(5,8$ pour cent). Si toutes les huit rechutes pendant la première semaine, et ne tenant pas compte de l'historique, étaient classifiées comme des cas d'insuccès, le taux d'insuccès était de 3,3 pour cent, et si toutes les 18 rechutes pendant les deux premières semaines étaient comptées de la même façon le taux était de 7,5 pour cent.

(4) Ces résultats étaient apparemment meilleurs que ceux obtenus quand 1,2 méga unités étaient employées, les pourcentages étant alors de 8,5, 5,0 , et 9,5 respectivement. Néanmoins l'analyse statistique de ces résultats montre que les différences ne sont pas grandes. Ce fait était probablement dû à une incidence relativement basse des gonocoques qui montraient une sensibilité bien moins marquée et qui étaient en circulation à ce moment, et demandait deux groupes comprenant beaucoup plus de malades pour indiquer une différence manifeste.

(5) Il est probable qu'au total le genre de sensibilité des souches de gonocoques en circulation qui va en diminuant continuera. Il est permis de faire d'autres augmentations substantielles dans le dosage de la procaïne pénicilline dans l'avenir, sans encourir des risques de toxicité, mais le facteur limite deviendra nettement la masse de tissu musculaire dans laquelle on pourra faire l'injection. De ce fait, il est nécessaire que la recherche d'autres traitements doit continuer comme sauvegarde pour l'avenir. 